\title{
Women Leadership, Culture, and Islam: Female Voices from Jordan
}

\author{
Tamer Koburtay $^{1} \cdot$ Tala Abuhussein $^{2} \cdot$ Yusuf M. Sidani $^{3}$
}

Received: 28 June 2021 / Accepted: 13 January 2022 / Published online: 28 February 2022

(c) The Author(s) 2022

\begin{abstract}
This paper aims to explore the experiences of female leaders considering the interplay of gender, religion, and culture. Drawing on an inductive-qualitative study, the paper examines perceptions regarding the role of religion and cultural norms in women's ascension into leadership positions in Jordan. The results indicated that Jordanian women leaders adopted an Islamic feminist worldview and did not embrace a liberal nor a socialist/Marxist feminist worldview. Women leaders seemed wanting to claim their religion back from those forces that are reportedly holding their aspirations hostage to monolithic interpretations of religious texts. By constantly referring to their religion, female leaders wanted to be granted spaces of trust and responsibility in leadership positions that they did not see contradictory to the way they understood their faith. The paper provides insights into how women leaders understand prejudicial stereotypes and discrimination in their society, explaining how those are linked to patriarchal socio-cultural traditions emphasizing male control.
\end{abstract}

Keywords Female leaders · Feminism · Gender · Islam · Qur'an

\section{Introduction}

The situation of women in Arab societies has received significant research attention given the grave situation that Arab women face ${ }^{1}$ (e.g., Abuhussein \& Koburtay, 2021; Afiouni, 2014; Althalathini et al., 2021; Koburtay \& Abuhussein, 2020; Koburtay et al., 2018; Maltby et al., 2010; Metcalfe, 2008; Sidani, 2005; Tlaiss, 2015). Some scholars assert that the situation of women in this region is related to significant cultural barriers inhibiting their growth and advancement (e.g., Abuhussein \& Koburtay, 2021; Karam \& Afiouni, 2017). The Arab culture, in general, seems to adopt the notion that women play a societal role that needs to be

Tamer Koburtay

tkoburtay@qu.edu.qa

Tala Abuhussein

Tala.Salah@uop.edu.jo

Yusuf M. Sidani

ys01@aub.edu.lb

1 College of Business \& Economics, Qatar University, Doha, Qatar

2 Faculty of Administrative \& Financial Sciences, University of Petra, Amman, Jordan

3 Olayan School of Business, American University of Beirut, Beirut, Lebanon distinct from that of men. While women have traditionally been involved in paid and unpaid work, the private space remains the primary one allocated to women. Women's participation in the public sphere has often been deemed scarce, sporadic, and temporary.

The aim of this paper is to explore how women leaders see their own plight and how they consider ways of addressing the continuous problems and opportunities they encounter, particularly in relation to the role of religious values and cultural traditions contributing to their current status. This builds on recent scholarly calls aiming to explore the interplay between Islam and feminism in specific cultural settings (Althalathini et al., 2021; Shaya \& Khait, 2017; Sidani et al., 2015; Tlaiss \& McAdam, 2021). Jordan is a fascinating context of study, given that it lies at the intersection of the more liberal Levant region and the more conservative Bedouin Arab cultural milieu (Abuhussein \& Koburtay, 2021; Majcher-Teleon \& Slimène, 2009). As such, drawing on an inductive reasoning approach informed by data collected from female leaders, the main question that this study seeks to answer pertains to which feminist voice is more salient among Jordanian female leaders and how they

\footnotetext{
1 The Arab/Middle East area was ranked as the second lowest region in the world based on the Gender Empowerment Measure (UNDP, 2012), while based on the Gender Gap Index (2018), the Middle East and North Africa rank as the lowest region in terms of gender parity (i.e., 60.2\%) (World Economic Forum, 2018).
} 
see the role of religion and cultural values in empowering or disempowering their ascension to leadership positions.

This study aspires to make several contributions to theory and practice. It moves beyond studies done in the Arab context that have been overwhelmingly concerned with issues related to gender discrimination (e.g., Bobbitt-Zeher, 2011), prejudice (e.g., Eagly \& Karau, 2002; Koenig et al., 2011; Spates et al., 2019), or women's employment (e.g., Afiouni, 2014), to zoom in more thoroughly on the interplay between women leadership, cultural context, and religious traditions. While we acknowledge the continuous interest in studying gender within management and organizational studies (e.g., Bastian et al., 2018; Bianco et al., 2017; Langowitz \& Minniti, 2007; Tlaiss \& McAdam, 2021), "the existing theoretical concepts need to be expanded to better explain the uniqueness of women ... as a subject of research inquiry" (Yadav \& Unni, 2016, p. 1) because, as suggested by Llewellyn and Trzebiatowska (2013, p. 245), "male-stream academia has marginalized feminist scholarship and [in the same way], feminist scholarship has marginalized religion." In response to this, this paper explore feminist approaches of female leaders in Jordan, and explains how these women perceive the role of religion and cultural traditions in impacting the potential of women to reach leadership positions in Jordanian institutions.

This paper is structured as follows. To embed this research in the current body of knowledge, a conceptual discussion regarding Islam, female leadership, and "historical" feminism in Arab societies is presented. The paper then explains the research methodology and findings. Finally, implications for research and practice are presented.

\section{Islam and Female Leaders in the Arab Culture}

In an increasingly globalized world, the Arab-Middle Eastern countries face challenges regarding social justice (or the lack thereof) and discrimination against females (Metcalfe, 2008). Females in this region are usually expected to balance their gender role (as mothers and wives) with their social role (as workers/leaders) (Grünenfelder, 2013; Mulvaney et al., 2007). Should they fail to harmonize between these roles, they may encounter some form of social exclusion. This mismatch harms females via adverse stereotypes and unequal treatment regarding their perceived abilities and leadership potential.

In many Muslim majority countries (MMCs), Islam is an important driver of ethical understandings and behaviors. Sources of religious guidance are embodied in the Qur'an (Holy Book of Muslims) and the Sunnah/Hadith, where the latter refers to the legacy and teachings of Prophet Muhammad comprising his words, acts, and deeds (Tlaiss, 2015). According to some scholars, a close reading of Islamic texts show that in Islam, there are directions that support complementarity between the sexes and encourage wider strategies to enhance diversity and avoid gender discrimination and inequality (Syed \& Ali, 2010; Syed et al., 2014). Barlas (2001) put it differently noting that, in Islamic understanding, males and females should "be treated differently, not unequally" (Metcalfe, 2008, p. 91).

Yet, there are other viewpoints that note linkages between religion, or religious understandings, and women's economic participation and leadership. A concept that has been thoroughly discussed in male-female societal interactions in Muslim societies, with direct implications for leadership, is related to the religious concept of qiwamah which roughly means men's custodianship over women (Sidani, 2018). This led some authors (e.g., El-Saadawi, 2013) to note that Islam advocates a form of patriarchy with the understanding that men should assume the role of leaders over women. Other authors disagree contending that a gender-conscious approach toward societal relationships in Muslim societies would lead to a more liberal interpretation of Islamic texts. Qiwamah under such approach means serving and protecting rather than leading or reigning over women's affairs (Bahlul, 2000; Banani, 1993; Sidani, 2018). This understanding led those scholars to assert that Islam does not promote men's unequivocal mastery in society (Syed \& Ali, 2010).

Understanding women's societal and leadership role is not restricted to variances in textual interpretations. The nature of early Muslim societies, and how they evolved historically, has had a significant impact on how women's role developed and changed. Marlow (1997), cited in Syed et al. (2014), argued that after Prophet Muhammad, rulers and Islamic scholars began to rationalize the tribal system emphasizing patriarchal understandings with the superiority of the male tribal chief. This eventually had implications on how people stereotype women positioning them with a lesser ability to lead (Ali, 1996; Khan, 2011; Koburtay et al., 2018). Over time, patriarchy became increasingly powerful in the ArabMiddle East region (Joseph, 1996), so women's presence in leadership positions became scant and exceptional. The ramifications of such practices had been reflected in women's low presence in leadership positions, dismal economic participation, and employment at levels below the global average (UNDP, 2012).

Contemporary scholarship about women leaders in Arab society has increased in the past few years but remains scattered and scarce. A literature search about women leadership in Arab societies generates 128 document results on Scopus. After filtering the results to only include articles on women leadership in business (excluding health, education, and other non-business journals), the number shrinks to merely 44 articles from 1995 to 2021. Many scholarly contributions approached the issue of women leadership in terms of what it means for their career ascension (e.g., Abalkhail, 2019; Jayashree et al., 2020). Other 
studies compared female leadership patterns and styles or attitudes toward female leadership (e.g., Kemp et al., 2015; Neal et al., 2007; Rayyan, 2016; Yaseen, 2010). Many studies assessed female leadership in specific Arab countries such as Oman (Al-Lamky, 2007), UAE (Madsen, 2010), Saudi Arabia (Hodges, 2017), and Lebanon (Sidani et al., 2015). Very few studies assessed the discourse of feminism within organizational circles. Some exceptions include Al-Mutawa (2020) who addressed state feminism and the persistent endorsement of sexist stereotypes and "myths". Prager (2020) also tackled the issue of state feminism and how it influences women's empowerment. Few studies assessed the interplay of feminism and religious understandings in influencing female entrepreneurship or career development (e.g., Althalathini et al.,'s 2021; Tlaiss \& McAdam, 2021). Up to our knowledge, no study has so far addressed feminist discourses of Arab women leaders, and how women leaders themselves perceive the intersection of culture and religion in influencing their ascension to leadership positions.

In this regard, it is important to discern which type of feminism resonates more among female leaders in Jordan, as the status of women in this country is currently undergoing a historic transition, with women achieving a number of positive gains and new rights. One justification for this transition could be attributed to the population in Jordan which includes a majority of Palestinians citizens and regarded as the highest portion to population of Palestinians worldwide (UNRWA, 2021). The influx of Palestinian refugees into Jordan back in the 1950s substantially influenced the Jordanian feminist movements, as an increasing number of women became involved in societal affairs bringing women's issues to the surface more forcefully (Smith, 2019). The Palestinian refugee population was more politicized and thus acted as a major driver of societal changes prompting demands for more political participation including the participation of women in the public sphere (Lowrance, 1998). The activism of Queen Rania in advancing women's issues to the forefront has also drawn lots of interest in the country and the region at large.

It is important to note that the discourses and transitions in feminist thought and action in Jordanian society cannot be separated from the discourses happening across the Arab world. Certain commonalities among most Arab countries with respect to the status of women meant that women passed through inter-related transitions all aiming at alleviating restrictions on their societal involvement and participation (Sidani \& Thornberry, 2010). A review about feminism in the Arab World in the next section would help us understand more about the research context in Jordan as it applies irrespective of minor nuances from one country to another.

\section{Multiple Feminisms of the Arab World}

Discrepancies in understanding the Muslim texts and how those were interpreted and utilized given a host of historical and cultural variables led to the emergence of what we call "multiple feminisms." Particularly in the last 150 years, there have been growing societal scholarly and grassroots movements to emancipate women and advance their status in Muslim and Arab societies. Of course, to draw a comprehensive account of how those movements materialized would not be possible given the varying experiences from countries as far east as Indonesia till as far West as Morocco. What is presented here, is particular to the Arab world, though a close scrutiny of the chain of events over the last century and a half would reveal several parallelisms across many contexts.

Arab feminist movements passed through multiple stages. The last few decades of the nineteenth century and the first few decades of the twentieth century witnessed the emergence of scholars and activists who advocated for women's societal rights. Because of colonial influences, many key personalities had the chance to interact with Western countries and get inspired by the women rights movements in those countries. Women's situation reached a dismal state in many Arab localities during that period prompting the emergence of grassroots movement aimed at the advancement of women. Qasim Amin (1863-1908), for example, in two landmark books lamented women's status and advocated for change. Huda Sha' arawi (1879-1947), the legendary women's rights advocate, is also credited for substantial political action and organizational prowess in support of women's rights. That era witnessed momentous and successive achievements for women in various countries in the region in terms of political rights and social inclusion. The 1940s and the 1950s witnessed wider female participation in nationalistic movements. Many of the feminist movements at the time were inspired by wider global discourse and emancipatory activities including those happening in socialist countries.

As a result, female access to education became more widespread, though still short of being ideal. Several regulatory reforms were introduced in many Arab countries, yet changing deep-rooted cultural structures proved harder to eradicate. In the 1960 s till the 1980 s, many countries witnessed the rise of state feminism with governments initiating change from above coupled with multiple legal reforms. Nawal El-Saadawi and Fatima Mernissi were among the figures who marked the Arab feminist movement considerably (El-Saadawi, 2013; Mernissi, 1987). Since the 1980s, Arab feminism took another turn witnessing a growing attention to linkages with religious traditions referring to what is perceived to be the emancipatory 
underpinnings of Islam. Those affiliated with this line of thinking are commonly referred to as Islamic feminists.

While their objectives are the same in terms of advancing women's issues, the above waves of Arab feminism do not represent distinct activities bound in time and location. Rather, one might think of these as "layers" where new approaches to feminism have been added with time, all working in parallel though with varying impact. Thus, multiple modes of feminism characterized Arab women's movements, starting with Western-inspired liberal approaches, then stepping into socialist perspectives, and then culminating in religious underpinnings. While all have strived to improve the status of women, they have adopted various approaches, sometimes putting them at odds with each other. Though united by having many common objectives, they have been divided by their analysis of the reasons behind the problems women face and the ways to resolve them. The above progression of feminist thought and action reflect three major feminist approaches that sometimes unite, and sometimes divide, Arab women: Liberal feminism, SocialistMarxist feminism, and Islamic feminism.

\section{Liberal Feminism}

A group of Arab women activists have pursued what would be considered closer to a liberal form of feminism linked to Western women's movements. This largely corresponds with second-wave feminism which associate emancipation of women with a "political agenda of individual autonomy, equal rights, and a commitment to liberal democracy" (Choudhury, 2009). Moghadam (2012) noted that in some respects, the feminist discourse in Arab countries was similar, though not identical, to that followed in some Western countries. Many benefits were perceived to emerge for women if they work within existing institutional settings as they strive to change discriminatory laws and structures that restrict women's societal ascension. Women in the West fought hard for their right to vote and work, and they have been able to reach a more equitable position. While still far from having perfect equality, Western women are argued to have made significant progress over the past few decades. This form of feminism and successes have had deep influences on Arab feminism.

Liberal feminism asserts that the emancipation and development of women requires work in terms of social policy in order to follow the successful initiatives implemented in the West. The major assumption behind this type of feminism is the understanding that women face common problems, and thus common solutions need to be devised. Despite recognizing cultural differences, the way forward for women under liberal feminism is to approach the universal challenges that marginalize women's presence in the public sphere. Those challenges transcend national boundaries, geographic structures, and cultural considerations. Under this mode of feminism, some scholars argue (Ezzat, 2016) that there had been an emphasis on the external role of women, that is, their role in the public sphere, at the expense of the internal role of women.

In sum, under the liberal perspective, "feminism is viewed as the result of Westernization: the adoption and adaptation of Western ideals, values and ways of life in Arabic culture" (Golley, 2004, p. 529). Liberal Arab feminists aspire to achieve change primarily through regulatory reforms, and thus work on influencing policy making. Hence, women's rights movements, under this worldview, aim to work within state institutions to make those more welcoming of women (Badran, 2005).

\section{Socialist-Marxist Feminism}

Liberal feminism does not cover the whole spectrum of the ideological underpinnings of women's liberation movements in the Arab world. Many Arab feminists and women movements were inspired by historic changes happening in socialist countries concerning women, and with the ideological framing of Marxism in understanding women's issues. The famous Nawal El-Saadawi, approached the case of women's predicament through what appears to be a Marxist lens by engaging the concept of class although she herself would have rejected this label (Obeid, 2005). Her rationalizations about women's issues went beyond what basic Marxism would problematize. She referred to societal structures in Arab societies that reaffirm patriarchal arrangements, and asserted that it would be wrong to separate the oppression that women face from class oppression. El-Saadawi argues that women are subjugated as they fall victim to a class society that is patriarchal, capitalistic, and dominated by men (Sidani, 2018). The link between the patriarchy and class is clear, as women face a form of oppression that is related not only to them being women, and therefore subjected to patriarchal structures, but is also related to class disadvantages. She argued that patriarchy needed to be defeated for women to be emancipated, and this cannot be accomplished without the eradication of capitalism. Moreover, El-Saadawi (2013) referred to the unique challenges facing women in the Third World as being related to imperialism, colonialism, and occupation. This explanation of women's marginalization go beyond a Marxist perspective of feminism limited to arguments related to economic inequalities generated from capitalistic structures.

Another example of such a perspective could be explored through reviewing the activism of feminists such as Sana' alMisri (1958-2000) and a group called Bint al-Ard, "Daughter of the Land" in Egypt (Hammad, 2011). Such feminism aims to achieve equal rights for women through addressing issues of unconditional gender and class equity. A staunch 
critic of the Islamic discourse, Al-Misri also refused the European model that tackles women's issues as being distinct from issues linked to social and class classifications. According to Hatem (1992, cited in Hammad, 2011, p. 228), "initiative and feminist awareness of women outside of Cairo, and the popular perspectives and diverse activities carried out by Bint al-Ard (...) made them more representative of Egyptian feminism at the present stage". Neither Sana'al-Misri nor Bint al-Ard used the religious argument to advance women's issues. They also criticized early male pioneers of female emancipation of the twentieth century, such as Qasem Amin and Rafaa al-Tehtawi, as the latter two built their arguments on an Islamic perspective.

Thus, the calamitous situation facing Arab women, according to this perspective, is related to the overwhelming role of capitalism and imperialism. The subjugation of women is not only understood in a Marxist framing in terms of the private control of means of production, which have been historically dominated by men, but also in terms of the unique challenges facing many women and men in the Arab world. The process by which women can be liberated can occur through the emancipation of the working class. This would ensure that women, who are currently the weaker partner in the production process, would be viewed as equal partners. Based on this understanding, capitalism has presented a significant threat to women, as it has instituted structures that have reaffirmed private male control over the means of production. Women have been relegated to the private sphere, not because of a specific religious understanding but because of the avaricious nature of capitalistic structures which undermine women's liberation.

\section{Islamic Feminism}

A third group of feminists approached women's issues through an Islamic lens noting that the sorry state of Arab women should be attributed to cultural and societal practices (Koburtay et al., 2018) and are thus not inherent to Islam (Syed \& Ali, 2010). Those scholars and activists advance a reconciliation between Islam and feminism (Hashim, 1999) looking for potential convergences between the two (Badran, 2013; Seedat, 2013). While the term's wide usage started in the 1990s (Kynsilehto, 2008), the approach is not new. When Hoda Shaarawi removed her face veil in the earlier part of the twentieth century, it was considered an act of insurgency. However, Shaarawi did not dissociate herself from the culture in which she was raised; she rationalized that the pitiful state of women could be linked to deeply rooted cultural barriers that have nothing to do with real religion. Others who came just before her or after her made similar rationalizations, asserting that advancing women's causes could be done through an act of reinterpreting what religion dictates regarding the roles of men and women (Ezzat, 2016).
The 1980s and 1990s, with the striking emergence of Islamic political movements, brought this discussion back to surface. Activists explored advancing the status of women through reinterpreting religious texts (Jawad, 2009), claiming that erroneous conceptions of some religious guidelines have discouraged the emancipatory potential of Islam (Anwar, 2018). Islamic feminists typically resort to the Qur' an and the Sunna, examine them critically, and reinterpret them with a gender-conscious (or women-friendly) lens (Ahmad, 2015). They refer to a historic male bias in interpreting religious texts (MirHosseini, 2006) that has led to restrictions on women's economic activity and their ability to reach leadership positions.

Thus, Islamic feminists suggest that women encounter problems related not only to patriarchal (and tribal) culture but also to misconceptions of Islamic principles (Joseph, 1996; Tlaiss, 2015). Wadud (2013) noted that it is erroneous to claim that gender inclusiveness is incongruent with Islam as the articulations of Islam underlie equality between the sexes. For example, what Islam requires of men that is different for women, such as the dress code, should not be used as an excuse for denying women from economic opportunities. Islamic feminists argue that the Qur'an affirms the essence of humanity shared between males and females, and that women are given the freedom, comfort, and social value necessary to participate in the economic life of their respective societies (Mehar, 2003).

The above three modes of feminism have all been active in Arab society across geographic contexts. Which voice is more salient might differ from one locality to another. We present below the specific case of Jordan attempting to assess how Jordanian women leaders view their own plight, and how they see the role of religion and cultural values in empowering or disempowering their ascension to leadership positions.

\section{Method}

\section{Research Design}

This research was carried out through a qualitative-inductive approach, using semi-structured interviews, as this approach allows researchers to gain in-depth insights into relevant phenomena and generate new knowledge and understanding of the topic under study. This methodology allows for a clearer understanding of the topic under study further developing thorough and conspicuous understandings. Participants were assured about confidentiality and that no information linked to a specific person would be disclosed. 


\section{Research Context-Women in Jordan}

In Jordan and other Arab countries, the negative stereotypes and prejudicial evaluations against women, together with non-inclusive policies and behaviors, create a legitimacy of discrimination against women (e.g., Koburtay et al., 2018). Jordan is known by its unique tribal, clan-centered and authoritarian norms and traditions. Religion plays a major role in Jordanian society and some scholars assert that interpretations of Islam are influenced by patriarchal misinterpretations and masculine practices (Afiouni, 2014; Syed et al., 2014). This makes women's contribution to the overall economic growth very limited (Barcucci \& Mryyan, 2014; Majcher-Teleon \& Slimène, 2009). In Jordan, when maintaining social standards and norms, women must primarily focus on starting a family or finding a husband, simply because men are the principal breadwinners and have the sole responsibility to provide for their families (Abuhussein $\&$ Koburtay, 2021).

In Jordan there is also a constitutional problem in Article 6 which states that "Jordanians shall be equal before the law, with no discrimination between them in rights and duties even if they differ in race, language or religion." (Jordan Constitution, Article 6, S1). While this Article pays attention to equality between people with different 'races', 'languages' and 'religions', it ignores gender issues. Accordingly, Jordan ranks in the bottom half among MENA (Middle East $\&$ North Africa) region in economic empowerment. As documented by the Social Security Corporation (2019), the gender gap exists in many industries. (e.g., tourism-73\%, construction-56\%, real estate-17\%). The gender gap in pay is also present (12\%). According to the Jordanian Department of Statistics, the unemployment of males (with at least a bachelor's degree) is $23 \%$, but is $78.2 \%$ for females (Al Khatib, 2020). Only 15 out of 130 seats in the Jordanian parliament are occupied by females (Inter-Parliamentary Union, 2021).

Taking a wider view, Jordan shares many cultural traditions (supported by patriarchal systems or Bedouin institutions) with many neighboring countries (e.g., Egypt, Syria, Iraq, Saudi Arabia, Qatar and UAE), but it differs in terms of granting women relatively more freedom such as a freedom to drive, vote and to work in senior positions (Koburtay \& Abuhussein, 2020; Koburtay et al., 2018). Still much is needed to happen before women are able to enjoy further rights related to their economic participation and presence in leadership positions.

Jordan is characterized by the presence of powerful tribes that play a dominant role in society; tribal systems influence various institutions and impact business functioning (Sawalha \& Meaton, 2012) and HR processes. The dominance of Bedouin tribalism has implications for women's economic participation and ascension to leadership positions. Tribal systems come with a set of inherent widely respected values that emphasize family, nobility, group bonds, honor, benevolence, chivalry, freedom, keeping promises, solidarity, and guarding against shame (Ibn-Khaldun, 2015). Still, there is, generally, an explicit bias against women in leadership positions (Al Maaitah et al., 2012). Tribal structures advance a form of paternalistic leadership (Neal et. Al. 2007), where the leader is expected to be a male acting as a father figure. This poses certain restrictions on the perceived role of women, particularly as potential leaders. Abu-Rabia-Queder (2007) asserted that women in Bedouin societies face problems due to the honor/shame conception, as they have to continuously guard against any potential shame resulting from meeting and working with strange men in the workplace. Honor in such societies is "placed almost exclusively on the shoulders of women" (Sonbol, 2003, p. 252).

\section{Participants}

The participants were involved in the study based on their ability to communicate and clearly articulate their experiences in a reflective and expressive manner. In total, 23 females working in leadership positions across various organizations participated in this study. The final sample covered a wide range of sectors, such as education, health care, and the police. The number of respondents was deemed suitable because later interviews added no incremental value and the data were deemed saturated; the ability to obtain additional insights was considered very limited beyond that level (Fusch \& Ness, 2015).

Table 1 presents a demographic profile about the participants.

\section{Recruitment}

This research adopted purposeful and snowball sampling techniques to identify and select relevant participants. The researchers purposefully targeted females who were leaders in businesses or organizations. The arrangements for the interviews were made through phone calls and emails. The researchers arranged in advance with the participants an appropriate time and place to conduct the interview. All participants were made aware of the research aims, the key questions, the expected duration of the interviews and their right to anonymity.

Having established the schedule of interviews, the researchers' responsibility was to follow the set schedule to conduct interviews over three months. The following section explains the procedure for conducting the interviews. 
Table 1 Interviewees' demographic

\begin{tabular}{|c|c|c|c|c|c|c|}
\hline & Position & Qualification & Tenure & Age & Gender & Marital status \\
\hline 1 & Director of the University President's Office & $\mathrm{PhD}$ in Business Administration & 22 & 45 & Female & - \\
\hline 2 & $\begin{array}{l}\text { Women Police Chief \& Manager of Institute for } \\
\text { Women's Police Training }\end{array}$ & High School & 17 & 68 & Female & Married \\
\hline 3 & Manager in an educational institution & $\mathrm{PhD}$ & 30 & 55 & Female & Married \\
\hline 4 & Officer-educational institution & Masters & 10 & 37 & Female & Married \\
\hline 5 & Assistant Professor- educational institution & $\mathrm{PhD}$ & 15 & 53 & Female & Married \\
\hline 6 & Personal Assistant Secretary- hospitality sector & Bachelor & 10 & 32 & Female & Single \\
\hline 7 & Head of department in a hospital & Bachelor- Jordanian Medical Board & 4 & 32 & Female & Married \\
\hline 8 & Owner of a local pharmaceutical company & Masters & 15 & 41 & Female & - \\
\hline 9 & Medical consultant & $\begin{array}{l}\text { Bachelor- Holder of American and } \\
\text { Jordanian medical board }\end{array}$ & 22 & 64 & Female & Divorced \\
\hline 10 & Manager in an educational institution & MBA & 12 & 45 & Female & Married \\
\hline 11 & Entrepreneur- Business owner & Bachelor & 18 & - & Female & Married \\
\hline 12 & Assistant professor & $\mathrm{PhD}$ & 3 & 33 & Female & Married \\
\hline 13 & Lecturer & $\mathrm{PhD}$ & 20 & 43 & & Married \\
\hline 14 & Professor & $\mathrm{PhD}$ & 22 & & Female & Widow \\
\hline 15 & Senior admin assistant & Bachelor & 3 & 25 & Female & Married \\
\hline 16 & School principal & Bachelor & 15 & 51 & Female & Married \\
\hline 17 & Management & Masters & 6 & 40 & Female & Single \\
\hline 18 & Lecturer & BA & 7 & 30 & Female & Married \\
\hline 19 & TFO & MBA & 10 & 35 & Female & Married \\
\hline 20 & Teacher & Masters & 2 & 35 & Female & Divorced \\
\hline 21 & - & $\mathrm{PhD}$ & 12 & - & Female & - \\
\hline 22 & CS & Bachelor & 4 & 27 & Female & Married \\
\hline 23 & Artist-Business owner & Bachelor & 11 & 31 & Female & Single \\
\hline
\end{tabular}

\section{Procedure and Ethics}

All interviews were conducted face to face by the authors of this paper. The interviews were conducted in English and Arabic. On average, interviews lasted for less than one hour, and were recorded upon approval being given by the interviewees and then transcribed verbatim.

The respondents were free to speak in the language they felt more comfortable with. One of the authors had previous experience in professional translation from English to Arabic and vice versa, and this made the task of translating the audio to transcripts a straightforward task. Some participants preferred to share their answers in writing, as they felt they needed more time to respond in their own words and to qualify their responses. This method gave the participants the freedom to explain with precision their experiences and beliefs.

Ethics were maintained and granted as follows. First, after thoroughly explaining the research goals and objectives, the researchers asked the participant to give their consent to participate in the study. Second, the participants were asked to give their permission for notes to be taken and for the interviews to be recorded. Third, the participants were informed that they had the right not to answer any question that they found personal/sensitive. All this information was explained by distributing an information sheet along with a consent form to all participants prior to their participation. Also, the participants were then anonymized in the transcripts.

\section{Interview Guide}

The interview guide was developed on the basis of the literature review and the researchers' intimate knowledge of Jordanian society. As explained above, this paper sets out one main question that needs to be answered: which feminist voice is more salient among Jordanian female leaders and how they see the role of religion and cultural values in empowering or disempowering their ascension to leadership positions?

The interview started with an introductory question regarding female leaders: "Did you face any institutional, organizational, or socio-cultural barriers when progressing to your position?" This question was followed by a question to stimulate the participant's thinking, i.e., "What is the role of women in your religion?" After these questions had been asked, other key questions were asked to cover the main 
objective in this study. Then, closing questions were offered such as, "In what way or ways has your religion affected other aspects of your life, and would you like to discuss any further issues related to your experience?" See "Appendix 1" for the interview guide.

\section{Data Coding and Analysis}

The researchers adopted Braun and Clarke's (2006) six phases of thematic analysis. This approach has been advocated in previous qualitative studies (e.g., Edwards \& FewDemo, 2016; Spates et al., 2019). In this study, the researchers started by transcribing the interviews, reading the transcripts and making notes to get an overall sense of what the participants had said. The next stage involved breaking down the data into units of meaning through a process of coding the responses (Braun \& Clarke, 2006). Also, a 'back and forth' movement between the transcripts, codes, and categories (Braun \& Clarke, 2006) was conducted because this could lead to a change in the preliminary analysis and permit new themes to emerge.

Based on the cluster of codes that emerged during the procedure described above, the researchers undertook further investigations of the data by (re-)reading the interview transcripts. Then, the major themes from different interviews were compared in order to identify similarities and differences across all the interviews. These steps in the analysis process resulted in a final list of themes that could be used to answer the main research question. Table 2 presents an overview of the findings organized by themes, descriptions, and supporting quotations. The identified themes are then discussed in detail in the next section.

\section{Results}

The results are organized by the dominant research question highlighted above. Data analysis identified three main themes and three sub-themes.

\section{Theme 1: Perceiving Islam: Myths and Realities}

Contrary to dominant perceptions about the potentially negative role of Islam for women's development, participants emphasized a positive role of Islam regarding female participation. Some participants emphasized that women enjoy "freedom of will" and have the right to participate in political, economic, and social events. One participant (FL3) referred to a Qur'anic verse in support of this perspective: "Whoever works righteousness, man or woman, and has Faith, verily, to him will We give a new Life, a life that is good and pure and We will bestow on such their reward according to the best of their actions" (16:97, Yusuf Ali).
Other participants (FL14 and FL11, respectively) noted the way they understood the influence of Islamic values on the status of women: "Islam does not distinguish between rights for males and females. On the contrary, Islam confers so many blessings on females whether they are in the family or in society at large". "Islam has given Muslim women many rights on various levels.... There is no barrier for a woman to be a leader, as long as she is competent to fill that position, and that is based on the understanding of the Qur'an, Sunna and, of course, scholars". Some participants looked very positively as to the role that women play within their own families, still emphasizing a gender role perspective (Eagly \& Sczesny, 2019; Eagly \& Wood, 2016).

I think in Islam, women have a very important role, even more important than a male's ability to make money and feed his kids because these are his responsibilities. Whereas, for a woman, her role is to raise her kids to be good people; be a supportive wife; a loving, caring daughter; a leader and influencer; someone who can take on so many responsibilities yet do more and be more. (FL2)

In relation to women and work, some participants agreed that females have the privilege to work in different occupations and perform at a level similar to men, except for some occupations. For example, FL9 highlighted that "females can ... access different occupations, with the exception of being the preeminent religious authority [Imama]", while FL16 explained that "Islam gave women the right to be a leader and take a responsible part in the society. It supports women".

What was important for many participants, however, was that a woman leader should maintain her set values following the general principles of Islam. This was clear in what FL2, among many others, said: "The most important thing for me when it comes to working [women] is obeying Allah's principles and guidance when I work". While there was a consensus among participants that Islam supports women's leadership and their success, clear distinctions were made as compared to men.

I think females should be raised from a young age to recognise their uniqueness and be supported in ways that help them bring out the best in themselves in order to grow and become productive Muslim women who can serve their families, institutions, and nations as best they can. (FL13)

Participants generally noted that while Islam places a high value on women's empowerment, misinterpretations abound. This idea was raised by FL11 by saying that "the problem is how people actually view and understand [Islam]; it is mostly influenced by the traditions and what people grow up knowing as rightful”. In support of this 
Table 2 Themes, description and codes

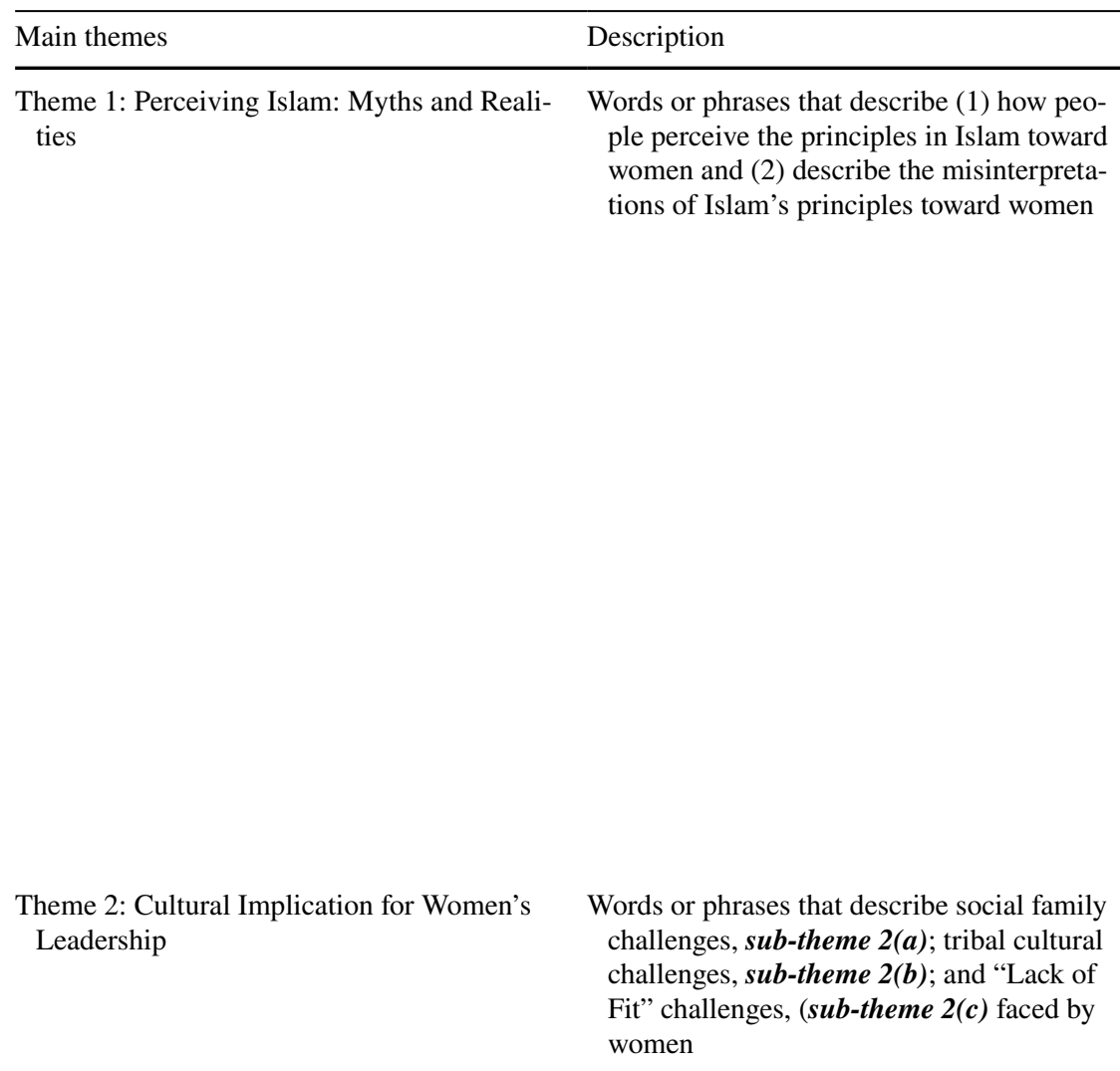

Sub-Theme 2(a): Social-family challenges

Sub-Theme 2(b): Tribal cultural challenges

Thematic codes

I think in Islam, women have a very important role

Islam general guidelines goes in line and support women

Islam has given Muslim women many rights on various levels

Islam supports women

Islam confers so many blessings for females

Islam gave women the right

Islam honored women in many verses in the Qur'an

Interpretation of Islam also varies between Muslim

Their interpretations are cultural rather than Islamic

Because of the culture like I said

Any wrong interpretation is up to the people themselves not religion

People misunderstand cultural and religious are two different things

This is again culture not Islam

They have returned to Jahiliyyah

It is mostly influenced by the traditions

Because I have a family

To give her time and mind to her home and children

Duty to serve their family and fulfill their social duties

The family and society

Does her responsibilities to her husband

Threat she's seen by her husband

Of course it is the culture behind all issues we face

Men-based society

Societal structure in Jordan assigns separate

roles for males and females

Hierarchical relationships

Culture and general traditions

Tribal culture and values concerning

Culture always has a role

Societal and tribal influences are the main obstacles to women's rights and advancement 
Table 2 (continued)

\begin{tabular}{|c|c|c|}
\hline Main themes & Description & Thematic codes \\
\hline Sub-Theme 2(c): "Lack of Fit" Challenges & & $\begin{array}{l}\text { She is considered emotional } \\
\text { Based on their gender } \\
\text { Women's role is molded in being a house wife } \\
\text { whose role is taking care of the family and the } \\
\text { children } \\
\text { Negative attitude toward female leadership } \\
\text { The attitude is that women are viewed nega- } \\
\text { tively } \\
\text { Woman is considered to be in kitchen } \\
\text { Many men, however, think that women need to } \\
\text { be housewives and complement their husband } \\
\text { The woman is governed by emotions more than } \\
\text { the mind, so she cannot be in a leadership } \\
\text { position } \\
\text { Because they expect females to be weak because } \\
\text { of their high emotions so the same }\end{array}$ \\
\hline Theme 3: Dominant mode of feminism & & $\begin{array}{l}\text { If you look at the Qur'an and Sunnah... } \\
\text { I believe Islam supports women to be leaders } \\
\text { Islam confers so many blessings for females } \\
\text { Islam gave women the right to be a leader } \\
\text { Islam honored women in many verses in the } \\
\text { Qur'an }\end{array}$ \\
\hline
\end{tabular}

view, other participants (e.g., FL6) noted that there are personal interpretations and false assumptions of the general principles of Islam: "Islam did not prevent or deny the work of women in leadership positions but people have moved away from their religion,.. by giving preference to males over females".

Misinterpretations, according to participants, are caused by "customs and traditions" and "extremism in people's understanding of religion". Further reasons were attributed to "culture and poor education" (FL3) and the educational system and how some men think (FL13); “... [False] education, of course, affects the mentality and way of thinking of the generations". Within similar lines, (FL23) noted that "men have gotten used to being the leaders for so long that it is a hard transition for them to accept women leading them when they have led for so long”.

\section{Theme 2: Cultural Implications for Women's Leadership}

This section aims to discuss the core challenges that the female leaders highlighted in their interviews. Three core sub-themes emerged from the interviews, which are linked to the challenges faced by female leaders. These problems, as explored by the female leaders, mainly reflect (a) social-familial, (b) tribal cultural, and (c) gender role stereotype challenges.

\section{Sub-Theme 2(a): Social-Family Challenges}

Participants shared the view that their society holds common prejudices that govern the actions and behaviors of women, such as stereotyping women as homemakers. One direct example was given by FL20, who said that "in some families, unfortunately, the woman is considered to belong only in the kitchen". FL13 further illustrated this point by saying:

On a personal level, I think a gap arises between women's need to develop their careers and their duty to serve their family and fulfil their social duties. The institution would not relieve women from any responsibilities based on their gender [neither are they expected to]. Equally, the family and society would not relieve them from their social duties to serve their family [and sometimes even their extended family]. So, unfortunately, women find themselves usually having to choose [either one or the other]. Otherwise, when trying to fulfil both responsibilities, it will be at the expense of their wellbeing and personal time. (FL13)

Participants referred to deep convictions in the Jordanian society that women's leadership role will conflict with their family duties - a conflict that should only be resolved in favor of family, and this negatively influences women contribution at work. For example, FL6 said that "middle managers believe that a female cannot bear the pressure of work; she is considered emotional or biased toward females, or believed to give her time and mind to her home 
and children". Some participants reflected the notion that women are perceived to lack the ability to balance their feminine role with their social or professional role:

In fact, where I work, I get paid less than the previous [manager], simply because they think I may not be able to focus on my roles and responsibilities [due to the fact that] I have a family and I am a woman". (FL1)

\section{Sub-Theme 2(b): Tribal Cultural Challenges}

Moving to the second category, as highlighted by female leaders, the most significant obstruction to female leaders was attributed to the tribal culture, which asserts male predominance and puts hindrances to women's ascension to leadership positions. For example, FL14 suggested that "societal and tribal influences are the main obstacles to women's rights and advancement". She also gave the following explanation:

The most perceived barriers of women's advancement in the Arab societies in general and Jordan in particular stem from societal origins not from religious origins. The societal structure in Jordan assigns separate roles for males and females. The role of females is structured within the family domain. (FL14)

Another participant (FL6) presented an example that is mentioned in the Qur'an stating how men, in the Pre-Islamic era, used to be ashamed of having daughters and would bury them alive (i.e., female infanticide). Some participants noted that although Islam has long condemned this practice -which has since been abandoned in Arab societies, some negative cultural practices remain. According to some participants, this is related to enduring masculine/patriarchal cultural norms. This does not mean that all cultural forces act in a negative manner:

Culture always has a role. [Some cultural influences] are positive some are negative. Positive in a sense that when a woman needs support, she would receive it. Negative in that it would sometimes underestimate the women's abilities and capacity to outperform some men. (FL18)

\section{Sub-Theme 2(c): "Lack of Fit" Challenges}

Moving to the third challenge faced by female leaders, participants noted that a common stance in Jordanian society reflects a strict perspective that women are not fit to occupy leadership positions. This "lack of fit" perspective has been identified in organizational research hindering women's occupational development (Heilman, 1983) which inhibits women from growing out of their domestic role in the home. As remarked by FL2 and FL3, respectively: "Many men, however, think that women need to be housewives and complement their husband, but never see their true potential of doing things in the best form possible"; "to be supportive and complementary to men's role...".

Participants reported the existence of deeply held stereotypes regarding women's fit for labor participation or ability to advance into leadership positions. Women are believed to be emotional, inclined to give preference to other women, not clever enough to handle complex tasks, and being indecisive, inefficient, and ineffective. All of these features are not conducive to women assuming leadership positions. As stated by FL1, "[our] community is a men-based society, and men believe that women are followers and leaders. This is where we need to put more effort into proving our abilities and showing that we can actually prove them wrong".

In general, the participants believed that people in Jordan generally perceive men as performing better in the upper ranks. The same participant commented as follows: "Yes, there are many cultural barriers that we face, like, they think that we, as females, are not as good at taking on highly sophisticated job roles or difficult roles simply because we are women". In addition, FL17 and FL13 both asserted that prejudicial evaluations still hinder women's leadership potential: "[there is a perception that] women are governed by emotions more than the mind, so she cannot be in a leadership position". "Within institutions, there seems to be a general preference to promote men. Women usually need to work twice as hard to prove they are eligible for a promotion".

\section{Theme 3: Dominant Mode of Feminism}

Participants consistently referred to Islam's principles and the Qur' anic verses to claim their rights, equality, and justice suggesting the prevalence of an Islamic feminist perspective. Many affirm that Islam condemns discrimination, prejudice, and injustice. For example, FL11 clearly stated that “... there is no barrier for a woman to be a leader as long as she is competent to fill that position, and that is based on the understanding of the Qur'an, Sunna and of course scholars. What is interesting across the data is that some participants suggested that leadership, in Islam, should not necessarily be defined as holding a title in order to have power. FL13 stated that women can be leaders for their families, communities, and nations.

Contrary to what many might think, a housewife is not relieved from leadership, which can be very challenging and demanding. I think females should be raised from a young age to recognise their uniqueness and be supported in ways that help them bring out the best in them in order to grow and become productive Muslim 
women who can serve their families, institutions, and nations as best they can.

Another example of how female leaders in this study use Islam as source of support, is FL14 who stated that "Islam does not separate rights between males and females. On the contrary, Islam confers so many blessings for females whether they are in the family or in society at large". Similarly, FL15 suggested that "Islam always encourages women to be successful and to lead", while FL16 said that "Islam gave women the right to be a leader and take a responsible role in society. It supports women". Further, FL17 commented as follows:

Islam honoured women in many verses in the Qur'an, and most of the Prophet's wives and companions had a role in leadership. For example, Aisha, the wife of the Prophet, peace be upon him, was known for her strength in medicine, history, and rhetoric. There are many Muslim women who have secured roles in national leadership, such as the former Prime Minister of Pakistan, President of Indonesia Megawati, Prime Minister of Turkey, and President of the Republic of Singapore, Halima Yaqoub, who transformed her country into the richest country in the world.

Overall, the participants used a positive interpretation of Islam to explain the potential of women in leadership positions, asserting that Islam reveres women and condemns gender discrimination and gendered stereotypical evaluations.

\section{Discussion}

There was an overwhelming sentiment that Islam, in and by itself, did not contribute to the dismal situation Muslim women have in their respective societies. In tandem with what was uncovered in prior studies addressing women's entrepreneurship or involvement in paid or unpaid work (e.g.,Althalathini et al., 2021; Karam \& Afiouni, 2017; Koburtay \& Abuhussein, 2020; Tlaiss \& McAdam, 2021), participants were clear in noting that Islam is not the culprit in explaining women's scarcity in leadership position. Throughout the interviews, the respondents clearly noted that cultural practices are often conflated with religious perspectives in a way that it becomes less clear to the foreign eye who is responsible for which. In some respects, the respondents generally wanted to communicate the notion that Islam does not discriminate against women. In other respects, they wanted to communicate the message that there is an element of "female uniqueness" that should not be ignored. In some ways, respondents did not address whether this uniqueness means that female presence at work needs to differ from that of men, or whether there are any clear repercussions on women's ascension to leadership positions. By referring back to Islam, and to religious edicts, in their discourse, those women reflected an overwhelming Islamic feminist perspective that is welcoming of what is thought to be a "proper" understanding of Islam against misinterpretations and misconceptions. These views lend support for Syed et al. (2014) and Afiouni's (2014) studies which suggest that patriarchal systems and tribal norms impact specific Islamic interpretations which in turn affect women in organizations and societies. Implicit in most of the participants' answers was a hidden critique, though most seemed unwilling to be vocal about the real culprit in advancing such misunderstandings.

Problems were also reported in relation to how misinterpretations of Islam are often convoluted with traditions and socio-cultural practices that make it hard for women to ascend into leadership positions. Female leaders encounter challenges arising from the patriarchal and tribal understandings that force a specific religious worldview. In line with prior research on this matter (Sidani, 2018; Tlaiss, 2015), religious practices become heavily influenced by local cultural traditions. Patriarchal structures that give rise to practices that are not friendly to women take shape in society and thus advance stereotypical understandings of what women can and cannot do. All of this leads to a common understanding that women are only fit to occupy certain roles within society (e.g., Eagly \& Karau, 2002; Eagly \& Wood, 2016). This could lead to discriminatory behaviors, including an accepted, often unquestioned, image of women belonging to the private sphere (home) rather than to the more extensive public sphere (wider society or workplace). More forcefully, certain tribal traditions complicate the process, emphasizing male predominance over societal affairs (see Koburtay et al., 2018). The Bedouin culture is very firm in Jordanian society (Rowland, 2009), and it emphasizes strict and distinct roles for men versus women. Most respondents seemed keen to refer to the many problems that women face attributing these to cultural/tribal practices.

One interesting thing about this study is that it illuminates on the influence of tribal values on women leaders in Jordan, even when those women are not members of tribes themselves. The study indeed reaffirmed the notion that cultural values, many of which are influenced by Bedouin tribalism, pose an impediment toward the emergence of women leaders in the Jordanian context. In tackling this problem, a top-down approach, totally abdicating tribal values, will not work. Many positive aspects within the cultural context could be retained and used to mitigate the sharp resistance to women leadership. In earlier research regarding democratic participation in Jordan, for example, Rowland (2009) suggested a process of social change that would leverage the dearly held tribal values that are 
compatible with democracy. Likewise, a gradual process that reframes some of the existing positive values might help advance the cause of women leaders in this context. There are some success stories in the Arab world that can be emulated. These include transformations happening in many countries in the Gulf Cooperation Council, where significant gains have been accomplished in women empowerment and leadership ascension despite existing tribal configurations. The objective is not to trivialize or marginalize tribal systems; such structures have existed for thousands of years and are not likely to be eradicated. Societal change agents need to engage the tribes themselves in the transformation process as any substantive change will not materialize if perceived as a form of external imposition.

On the other hand, some women referred to the dominance of certain laws and regulations that inhibit women's ascension, yet they did not emphasize that a regulatory approach would significantly help. Indeed, there are some laws that inhibit women's ability to join or grow within their organizations (Khalaf et al., 2015). In that, respondents did not elaborate what institutional mechanisms needed to change or develop within business organizations to advance the situation of women. They did not show much affinity to a Western style of feminism based on mimicking women's rights movements in different parts of the world. References to specific laws were detected in the interviews, yet there did not seem to be an over-riding desire to approach women's emancipation through this approach. Does this mean that the respondents were content as to the prevalent laws found in Jordanian society? We cannot make such a claim here, but our contention is that the respondents asserted that changes needed to happen at a deeper level, at the level of attitudes and beliefs. This would be a much harder battle to fight requiring significant efforts.

By affirming that they see an emancipatory role of Islam, despite patriarchal interpretations, women leaders were discontent with the problematic tribal structures and norms limiting their participation and potential for leadership. Religious misinterpretations are bound to happen (Syed \& Ali, 2010) and will not cease to influence societal behavior. Women leaders lamented how Islam is erroneously positioned and how socio-cultural forces use it to advance their agendas. Women seemed wanting to claim their religion back from those forces that hold their aspirations hostage to narrow mindsets revolving around male control. By constantly referring to the emancipatory potential of their religion, they wanted to be granted spaces of trust and responsibility in leadership positions that they did not see contradictory to the way they understood their faith. Again, this reflected an overwhelming Islamic feminist perspective where female leaders sharply criticized patriarchal interpretations of religious texts, looking at religion not as a source of "male control" but as a potential source of emancipation and liberation (Akhmetova, 2016; Sidani, 2005).

While references were made to patriarchal structures, those were not framed within a strict Marxist perspective emphasizing class divisions contrary to what El-Saadawi (2013) would have argued. Tribal structures transcend class arrangements, as tribes dominate many institutional arrangements in public and private life. They are found in the government and public sector, in the army, and in business communities (Furr \& Al-Serhan, 2008). They include individuals belonging to various economic groups; some are wealthy business people, while others belong to the working class (Cole, 2003). In a strict Bedouin society, Marxist arguments are not likely to gain force as people are more likely to be aligned with tribal affiliations rather than class divisions. There were no noticeable references to the role of capitalistic structures that might align with patriarchal forces to inhibit women's ascension in business or to leadership positions.

While most respondents referred to religious texts, quoting from the Qur' an and the Sunnah, no one referred to one of the famous Arab feminists aligned with liberal or Marxists worldviews that dominated feminist activity in other countries, most notably Egypt (e.g., El-Saadawi 2003). After decades of female activism, it is surprising that the struggles of many Arab feminists seemed not to be noticed, or were ignored by those female leaders. While our study did not particularly ask about the influence of those activists on their worldviews, the absence of referring back to those feminists was astounding. Further research is needed to uncover clearly whether this was a happenstance of the research question, or whether liberal and Marxist feminist worldviews actually did not take hold in Jordan. If the latter is the case, it would be interesting to understand why someone like Sana' al-Misri or Nawal El-Saadawi or other renowned Arab feminists did not seem relevant in the discourses of Jordanian female executives. The dominance of an Islamic worldview reflecting an Islamic feminist perspective seemed the most important voice articulated by those women.

\section{Limitations and Future Research}

The current study is limited in the ways that can be addressed by future research. As a qualitative study, the number of the respondents was limited to 23 though this number was considered to have reached saturation. The sample is not representative of all women, as it purposefully targeted female leaders who succeeded in shattering the glass ceiling and reached leadership positions within businesses and organizations. Our study did not particularly target Bedouin women; a follow-up study could aim at assessing the perspectives of female workers or leaders with clear Bedouin backgrounds.

Researchers are invited to build upon the present study by identifying contexts that may allow for a further separate 
analysis of various demographic groups, such as age, race, and ethnicity. Also, given that there are more similarities than differences between the views/beliefs of female leaders, the replication of this study in another Arab or Muslim majority country may provide further validation and generalizability of the key findings of this study.

Further, interviews with female leaders are limited by our focus on women who have successfully overcome gender discrimination and thus serve in leadership positions. Our study does not include women who were not promoted to leadership levels due to gender bias or discrimination. The sentiment of those women who failed might have not been completely captured. One key justification as to why the authors did not interview other groups of women is derived from the main aim of the present study. Therefore, gaining insights from women who are not leaders is not directly linked with the paper's aim. Also, our sample does not include non-Muslim participants. It would be plausible that a sample of less successful women and/or non-Muslim female leaders might reveal different views and perspectives.

Finally, one worthwhile area of investigation revolves around studying linkages between normative Islam, Muslim scholars' interpretations-such as Imams and Muftis (i.e., jurists qualified to give authoritative opinions known as fatwas)_- and Islamic feminists. This would help uncover variances in interpretations of what religion entails between those different communities, helping to identify gaps that need to be addressed in Muslim thinking and practice.

\section{Implications}

This paper contributes to the scarce knowledge that currently exists on how female leaders perceive the role of their religion in their leadership ascension. The study moves beyond earlier findings that are merely concerned with issues related to gender discrimination, sexual relations, or women's employment. The present study discussed the position of female leaders vis-à-vis their religion and the religious texts, and how this links to gender and socio-cultural values/traditions. The evidence brought forward from the interviews provides insights into how women leaders understand prejudicial stereotypes and discrimination and how those are linked to patriarchal socio-cultural traditions. The study uncovers the voice of Jordanian women leaders as they navigate their position within the institutional setup in their workplaces and reflect on the reasons behind the challenges they faced, or continue to face. This, of course, has relevance and implications beyond the context of Jordan as the issues presented are commonplace across the Arab world. Whether women in other Arab counties have similar experiences, or approach issues similar to those of Jordanian women, would be an interesting and worthwhile endeavor for future research.

From a practical perspective, devising recommendations that would help in working around tribal structures and patriarchal understandings and practices is not an easy feat. Some changes are needed to occur at the cultural level, with significant governmental commitment, which might take many more years to materialize. Still, operating at the organizational level might work to at least to partially alleviate the problems facing women and their leadership ascension. Earlier research has referred to the role of indigenous managerial practices and understandings in reaching meaningful change in Arab societies (Sidani \& Thornberry, 2010). In addition, advancing women leadership in the region requires, beyond fair and equitable HR policies and organizational practices welcoming of women, an engagement of a progressive religious discourse (Syed \& Ali, 2010), publicizing of success stories of women in management (Itani et al., 2011), and smartly navigating through the tribal structures (Rowland, 2009).

\section{Conclusion}

Jordan and, more generally, Arab societies have a lot to gain from an increased involvement of women in leadership. Amidst all the problems in the Arab world, at the political, organizational, and societal levels, a more balanced representation of women in leadership would be an important step toward societal development and a vital contributor to a more just, productive, and inclusive society. In this paper, we explored how women leaders describe the source of their problems and the ways to tackle those problems, and how they explain the power of various forces in facilitating or impeding their leadership journeys. The study also reflects their positions on the interplay between religious understandings and cultural norms/practices in explaining their empowerment or disempowerment. The study revealed how female leaders lamented the disheartening power of patriarchal socio-cultural values in inhibiting women's ascension into leadership positions. In cultural settings that nurture a stereotype of women as being unfit to be leaders, women, and their societies, have a lot to lose, particularly if such a position is supported by a monolithic interpretation of what religion entails. 


\section{Appendix 1: Interview Guide}

\begin{tabular}{|c|c|c|}
\hline $\begin{array}{l}\text { Type of ques- } \\
\text { tions }\end{array}$ & Questions & Objective of question \\
\hline Demographic & $\begin{array}{l}\text { 1. Age } \\
\text { 2. Female/male } \\
\text { 3. Education completed } \\
\text { 4. Years at this company } \\
\text { when receiving the job } \\
\text { 5. Marital status }\end{array}$ & Descriptive data \\
\hline $\begin{array}{l}\text { Opening and } \\
\text { motiva- } \\
\text { tional } \\
\text { questions }\end{array}$ & $\begin{array}{l}\text { Are there any institutional, } \\
\text { organizational or socio- } \\
\text { cultural barriers you faced } \\
\text { while progressing to your } \\
\text { position? } \\
\text { What is the role of women in } \\
\text { your religion? }\end{array}$ & $\begin{array}{l}\text { Stimulate participant's } \\
\text { thinking }\end{array}$ \\
\hline $\begin{array}{l}\text { Key ques- } \\
\text { tions }\end{array}$ & $\begin{array}{l}\text { How do you perceive the } \\
\text { Islamic guidelines toward } \\
\text { women in leadership posi- } \\
\text { tions? } \\
\text { What aspect of religion has } \\
\text { the strongest influence in } \\
\text { your work-life? } \\
\text { How do you think that } \\
\text { "Islam" has influenced the } \\
\text { way you view "women's } \\
\text { leadership"? } \\
\text { Do you think that the inter- } \\
\text { pretation of Islam in your } \\
\text { country differs from its } \\
\text { original guidelines toward } \\
\text { women? } \\
\text { What do you think are some } \\
\text { of the major misinterpreta- } \\
\text { tions of your religion "in } \\
\text { relation to women's leader- } \\
\text { ship"? What is the main } \\
\text { reason for such misinter- } \\
\text { pretation? } \\
\text { Can you elaborate on the } \\
\text { role of culture in advanc- } \\
\text { ing or impeding the ascen- } \\
\text { sion of women in society? } \\
\text { Are there aspects of the } \\
\text { culture in which we live } \\
\text { that have proven to be ben- } \\
\text { eficial to women's causes } \\
\text { in the Jordanian society? }\end{array}$ & $\begin{array}{l}\text { Answering the } \\
\text { research question }\end{array}$ \\
\hline $\begin{array}{l}\text { Closing } \\
\text { questions }\end{array}$ & $\begin{array}{l}\text { In what way or ways has } \\
\text { your religion affected other } \\
\text { aspects of your life? } \\
\text { Would you like to discuss } \\
\text { any further issues related } \\
\text { to your experience? }\end{array}$ & Closing the interviews \\
\hline
\end{tabular}

Funding Open Access funding provided by the Qatar National Library.

\section{Declarations}

Conflict of interest The authors declare that they have no conflict of interest.

Research Involving Human Participants and/or Animals This paper does not contain any studies with animals performed by any of the authors.

Informed Consent Informed consent was obtained from all individual participants included in the study.

Open Access This article is licensed under a Creative Commons Attribution 4.0 International License, which permits use, sharing, adaptation, distribution and reproduction in any medium or format, as long as you give appropriate credit to the original author(s) and the source, provide a link to the Creative Commons licence, and indicate if changes were made. The images or other third party material in this article are included in the article's Creative Commons licence, unless indicated otherwise in a credit line to the material. If material is not included in the article's Creative Commons licence and your intended use is not permitted by statutory regulation or exceeds the permitted use, you will need to obtain permission directly from the copyright holder. To view a copy of this licence, visit http://creativecommons.org/licenses/by/4.0/.

\section{References}

Abalkhail, J. M. (2019). Women's career development in an Arab Middle Eastern context. Human Resource Development International, 22(2), 177-199.

Abuhussein, T., \& Koburtay, T. (2021). Opportunities and constraints of women entrepreneurs in Jordan: An update of the 5Ms Framework. International Journal of Entrepreneurial Behavior \& Research., 27(6), 1448-1475. https://doi.org/10.1108/ IJEBR-06-2020-0428

Abu-Rabia-Queder, S. (2007). The activism of Bedouin women: Social and political resistance. HAGAR: Studies in Culture Polity and Identities, 7, 67-85. Retrieved from http://www.bgu.ac.il.

Afiouni, F. (2014). Women's careers in the Arab Middle East: Understanding institutional constraints to the boundary less career view. Career Development International, 19(3), 314-336. https://doi. org/10.1108/CDI-05-2013-0061

Ahmad, A. (2015). Islamic feminism-a contradiction in terms?. Friedrich-Ebert-Stiftung.

Akhmetova, E. (2016). Women in Islamic civilisation: Their rights and contributions. Islam and Civilisational Renewal (ICR), 7(4), 474-491.

Al Khatib, M. (2020). Facilitating female employment in Jordan: Key Issues and Trends. UNESCO Education Sector. Retrieved from https://unevoc.unesco.org/yem/Female+unemployment+in+Jordan+YEM+Blog\&context

Al-Lamky, A. (2007). Feminizing leadership in Arab societies: The perspectives of Omani female leaders. Women in Management Review, 22(1), 49-67.

Al Maaitah, R., Oweis, A., Olimat, H., Altarawneh, I., \& Al Maaitah, H. (2012). Barriers hindering Jordanian women's advancement to higher political and leadership positions. Journal of International Women's Studies, 13(5), 101-122. 
Al-Mutawa, R. (2020). I want to be a leader, but men are better than women in leadership positions: State feminism and legitimizing myths in the United Arab Emirates. Hawwa, 18(1), 31-50.

Ali, A. J. (1996). Cultural discontinuity and Arab management thought. International Studies of Management \& Organization, 25(3), 7-30.

Althalathini, D., Al-Dajani, H. \& Apostolopoulos, N. (2021). The Impact of Islamic Feminism in Empowering Women's Entrepreneurship in Conflict Zones: Evidence from Afghanistan, Iraq and Palestine. Journal of Business Ethics. https://doi.org/10.1007/ s10551-021-04818-z

Anwar, E. (2018). A genealogy of Islamic feminism: Pattern and change in Indonesia. Routledge.

Badran, M. (2005). Between secular and Islamic feminism/s: Reflections on the Middle East and beyond. Journal of Middle East Women's Studies, 1(1), 6-28.

Badran, M. (2013). Feminism in Islam: Secular and religious convergences. Simon and Schuster.

Bahlul, R. (2000). On the Idea of Islamic Feminism. Journal of Islamic Studies, 20, 34-63.

Banani, F. (1993). Taqseem al- 'amal baina al-Rajul wa al-Mar'ah (Division of labor between men and women. (Marrakesh: Manshurat Kulliyat al-'Ulum al-Qanuniyya)

Barcucci, V., \& Mryyan, N. (2014). Labour market transitions of young women and men in Jordan. International Labour Organisation.

Barlas, A. (2001). Muslim women and sexual oppression: Reading liberation from the Quran. Macalester International, 10(1), 117-146.

Bastian, B. L., Sidani, Y. M., \& Amine, Y. E. (2018). Women entrepreneurship in the Middle East and North Africa: A review of knowledge areas and research gaps. Gender in Management: An International Journal, 33(1), 14-29.

Bianco, M. E., Lombe, M., \& Bolis, M. (2017). Challenging gender norms and practices through women's entrepreneurship. International Journal of Gender and Entrepreneurship, 9(4), 338-358.

Bobbitt-Zeher, D. (2011). Gender discrimination at work: Connecting gender stereotypes, institutional policies, and gender composition of workplace. Gender \& Society, 25(6), 764-786.

Braun, V., \& Clarke, V. (2006). Using thematic analysis in psychology. Qualitative Research in Psychology, 3(2), 77-101.

Choudhury, C. A. (2009). Empowerment or Estrangement?: Liberal Feminism's Visions of the "Progress" of Muslim Women. University of Baltimore Law Forum, 39(2), 3.

Cole, D. P. (2003). Where have the Bedouin gone? Anthropological Quarterly, 235-267.

Eagly, A. H., \& Karau, S. J. (2002). Role congruity theory of prejudice toward female leaders. Psychological Review, 109(3), 573-598.

Eagly, A. H., \& Sczesny, S. (2019). Gender roles in the future? Theoretical foundations and future research directions. Frontiers in Psychology, 10, 1965.

Eagly, A. H., \& Wood, W. (2016). Social role theory of sex differences. The Wiley Blackwell Encyclopedia of Gender and Sexuality Studies, 1-3.

Edwards, A. L., \& Few-Demo, A. L. (2016). African American maternal power and the racial socialization of preschool children. Sex Roles, 75(1-2), 56-70.

El-Saadawi, N. (2013). The Essential Nawal El Saadawi: A Reader. Zed Books Ltd.

Ezzat, H. R. (2016). Women and Ijtihad: Towards a New Islamic Discourse. Al-Raida Journal, 12-33.

Furr, A., \& Al-Serhan, M. (2008). Tribal customary law in Jordan. South Carolina Journal of International Law and Business, 4(2), 3.

Fusch, P. I., \& Ness, L. R. (2015). Are we there yet? Data saturation in qualitative research. The Qualitative Report, 20(9), 1408-1416.
Golley, N. A. H. (2004). Is feminism relevant to Arab women? Third World Quarterly, 25(3), 521-536.

Grünenfelder, J. (2013). Negotiating gender relations: Muslim women and formal employment in Pakistan's rural development sector. Gender, Work \& Organization, 20(6), 599-615. https://doi.org/ 10.1111/j.1468-0432.2012.00609.x

Hammad, H. (2011). The other extremists: Marxist feminism in Egypt, 1980-2000. Journal of International Women's Studies, 12(3), 217-233.

Hashim, I. (1999). Reconciling Islam and feminism. Gender \& Development, 7(1), 7-14.

Heilman, M. E. (1983). Sex bias in work settings: The lack of fit model. Research in Organizational Behavior, 5, 269-298.

Hodges, J. (2017). Cracking the walls of leadership: Women in Saudi Arabia. Gender in Management, 32(1), 34-46.

Ibn-Khaldun, I. (2015). The muqaddimah: An introduction to historyabridged Edition. Princeton University Press.

Inter-Parliamentary Union. (2021). Jordan Majlis Al-Nuwaab (House of Representatives). Retrieved from https://data.ipu.org/content/ jordan?chamber_id=13434.

Itani, H., Sidani, Y. M., \& Baalbaki, I. (2011). United Arab Emirates female entrepreneurs: Motivations and frustrations. Equality, Diversity and Inclusion: An International Journal, 30(5), 409-424.

Jawad, H. (2009). Islamic feminism: Leadership roles and public representation. Hawwa, 7(1), 1-24.

Jayashree, P., Lindsay, V., \& McCarthy, G. (2020). Career capital development of women in the Arab Middle East context: Addressing the pipeline block. Personnel Review., 50(4), 1253-1278.

Joseph, S. (1996). Patriarchy and development in the Arab world. Gender \& Development, 4(2), 14-19.

Karam, C. M., \& Afiouni, F. (2017). Women and the legitimization of (not) engaging in paid work: Logics from Lebanon. Career Development International, 22(6), 628-658. https://doi.org/10. 1108/CDI-09-2016-0148

Kemp, L. J., Madsen, S. R., \& Davis, J. (2015). Women in business leadership: A comparative study of countries in the Gulf Arab states. International Journal of Cross Cultural Management, $15(2), 215-233$

Khalaf, Z. M., Nakhaleh, L. A., \& Sara, M. W. A. (2015). Women's participation in the workforce-challenges and characteristics in Jordan. Middle East Journal of Business, 10(3), 41-58.

Khan, S. A. (2011). Convergence, divergence or middle of the path: HRM model for Oman. Journal of Management Policy and Practice, 12(1), 76-87. Retrieved form http:// search.proquest.com/ docview/876865220?pq-origsite $=$ gscholar.

Koburtay, T., \& Abuhussein, T. (2020). Normative Islam, prejudice and women leaders: Why do Arab women leaders suffer. Journal of Gender Studies, 30(2), 177-189. https://doi.org/10.1080/09589 236.2020.1863195

Koburtay, T., Syed, J., \& Haloub, R. (2018). Implications of religion, culture, and legislation for gender equality at work: Qualitative insights from Jordan. Journal of Business Ethics, 164(3), 421436. https://doi.org/10.1007/s10551-018-4036-6

Koenig, A. M., Eagly, A. H., Mitchell, A. A., \& Ristikari, T. (2011). Are leader stereotypes masculine? A meta-analysis of three research paradigms. Psychological Bulletin, 137(4), 616-642. https://doi.org/10.1037/a0023557

Langowitz, N., \& Minniti, M. (2007). The entrepreneurial propensity of women. Entrepreneurship Theory and Practice, 31(3), 341-364.

Lowrance, S. R. (1998). After Beijing: Political liberalization and the women's movement in Jordan. Middle Eastern Studies, 34(3), 83-102.

Madsen, S. R. (2010). Leadership development in the United Arab Emirates: The transformational learning experiences of women. Journal of Leadership \& Organizational Studies, 17(1), 100-110. 
Majcher-Teleon, A. M., \& Slimène, O. B. (2009). Women and Work in Jordan: A case study of tourism and ICT sectors. European Training Foundation.

Maltby, L. E., Hall, M. E. L., Anderson, T. L., \& Edwards, K. (2010). Religion and sexism: The moderating role of participant gender. Sex Roles, 62(9-10), 615-622.

Mehar, I. A. (2003). Al-Islam: Inception to conclusion. Library of congress.

Mernissi, F. (1987). Beyond the veil: Male-female dynamics in modern Muslim society (Vol. 423). Indiana University Press, Bloomington, Indiana.

Metcalfe, B. D. (2008). Women, management and globalization in the Middle East. Journal of Business Ethics, 83(1), 85-100.

Mir-Hosseini, Z. (2006). Muslim women's quest for equality: Between Islamic law and feminism. Critical Inquiry, 32, 629-645.

Moghadam, V. M. (2012). Globalization and social movements: Islamism, feminism, and the global justice movement. Rowman \& Littlefield.

Mulvaney, R. H., O'Neill, J. W., Cleveland, J. N., \& Crouter, A. C. (2007). A model of work-family dynamics of hotel managers. Annals of Tourism Research, 34(1), 66-87. https://doi.org/10. 1016/j.annals.2006.07.002

Neal, M., Finlay, J. L., Catana, G. A., \& Catana, D. (2007). A comparison of leadership prototypes of Arab and European females. International Journal of Cross Cultural Management, 7(3), 291-316.

Obeid, R. (2005). The feminist thought of Nawal Saadawi. (2005) (Master's dissertation, Lebanese American University), Beirut, Lebanon..

Prager, L. (2020). Emirati Women Leaders in the Cultural Sector: From "State Feminism" to Empowerment? Hawwa, 18(1), 51-74.

Rayyan, M. (2016). Jordanian women's leadership styles in the lens of their masculinity-femininity value orientation. Journal of Transnational Management, 21(3), 142-161.

Rowland, J., (2009) Democracy and the Tribal System in Jordan: Tribalism as a Vehicle for Social Change. Independent Study Project (ISP) Collection. 749. https://digitalcollections.sit.edu/isp_colle ction/749.

Sawalha, I., \& Meaton, J. (2012). The Arabic culture of Jordan and its impacts on a wider Jordanian adoption of business continuity management. Journal of Business Continuity \& Emergency Planning, 6(1), 84-95.

Seedat, F. (2013). Islam, feminism, and Islamic feminism: Between inadequacy and inevitability. Journal of Feminist Studies in Religion, 29(2), 25-45.

Shaya, N., \& Khait, R. A. (2017). Feminizing leadership in the Middle East: Emirati women empowerment and leadership style. Gender in Management: An International Journal., 32(8), 590-608.

Sidani, Y. (2005). Women, work, and Islam in Arab societies. Women in Management Review, 20(7), 498-512.

Sidani, Y. M. (2018). Muslim women at work. Palgrave Macmillan.
Sidani, Y., Konrad, A., \& Karam, C. M. (2015). From female leadership advantage to female leadership deficit: A developing country perspective. Career Development International, 20(3), 273-292.

Sidani, Y. M., \& Thornberry, J. (2010). The current Arab work ethic: Antecedents, implications, and potential remedies. Journal of Business Ethics, 91(1), 35-49.

Smith, J. (2019). Jordanian feminism and countering violent extremism. Brown Political Review. Retrieved from https://brownpolit icalreview.org/2019/03/jordanian-feminism-countering-violentextremism/

Social Security Corporation. (2019). Annual report 2019: Statistical Appendix. Jordan: Social Security Corporation.

Sonbol, A. E. A. (2003). Women of Jordan: Islam, labor, and the law. Syracuse University Press.

Spates, K., Na'Tasha, M. E., Watts, B. C., Abubakar, N., \& James, T. (2019). Keeping ourselves sane: A qualitative exploration of Black women's coping strategies for gendered racism. Sex Roles, 1-12.

Syed, J., \& Ali, A. J. (2010). Principles of employment relations in Islam: A normative view. Employee Relations, 32(5), 454-469. https://doi.org/10.1108/01425451011061630

Syed, J., Van Buren, I. I. I., \& Harry, J. (2014). Global business norms and Islamic views of women's employment. Business Ethics Quarterly, 24(2), 251-276. https://doi.org/10.5840/beq201452910

Tlaiss, H. A. (2015). How Islamic business ethics impact women entrepreneurs: Insights from four Arab Middle Eastern countries. Journal of Business Ethics, 129(4), 859-877.

Tlaiss, H. A., \& McAdam, M. (2021). Unexpected lives: The intersection of Islam and Arab women's entrepreneurship. Journal of Business Ethics, 171(2), 253-272.

United Nations Development Programme. (2012). Gender equality and women's empowerment in public administration: Jordan case study. UNDP.

UNRWA. (2021). UNRWA In figures 2020-2021. Retrieved from https://www.unrwa.org/resources/about-unrwa/unrwa-figur es-2020-2021

Wadud, A. (2013). Inside the gender jihad: Women's reform in Islam. Oneworld Publications.

World Economic Forum (2018) The global gender gap report. Cologny/Geneva Switzerland: World Economic Forum. Retrieved from https://www.weforum.org/reports/ the-global-gender-gap-report-2018.

Yadav, V., \& Unni, J. (2016). Women entrepreneurship: Research review and future directions. Journal of Global Entrepreneurship Research, 6(1), 1-18.

Yaseen, Z. (2010). Leadership styles of men and women in the Arab world. Education, Business and Society: Contemporary Middle Eastern Issues, 3(1), 63-70.

Publisher's Note Springer Nature remains neutral with regard to jurisdictional claims in published maps and institutional affiliations. 